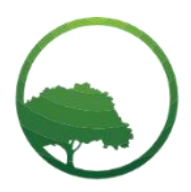

Research in Business \& Social Science

\title{
Levels of transparency and county service delivery in Kenya
}

\author{
Kellen Kiambati \\ Karatina University Human Resource Development Department, P.O. BOX 1957 - 10101, Karatina - Kenya
}

\author{
A R T I CLE INFO \\ Article history: \\ Received 28 December 19 \\ Received in revised form 05 Feb. 20 \\ Accepted 12 February 20

\section{Keywords:} \\ Levels, Transparency, Service, \\ Participation, Communication \\ JEL Classification: \\ H10, H70, H40
}

\begin{abstract}
A B S T R A C T
In order to push development to the grassroots and ensure citizens contribute meaningfully to development, many African countries have adopted the devolved governance system. However, it has been observed that the devolution of political powers has not translated equally to envisioned overall development. In Kenya County governments have achieved various milestones towards development demonstrated through the infrastructure, social amenities, and standards of living. However, corruption has been increasing mainly due to a lack of transparency. This paper sought to examine the contribution of transparency levels in County government service delivery. The study adopted mixed method approach using survey and in-depth interviews concurrently. Stratified multi stage cluster sampling was deployed. Quantitative data was collected using questionnaires and qualitative data using interview schedules. Data was analyzed using descriptive and inferential statistics and a typological theory developed to explain the study results. The study findings showed that the level of transparency in the counties was low which affected service delivery. The study concluded that county governments should ensure that public participation and sharing of information is bidirectional to involve both users and management so as to improve service delivery.
\end{abstract}

(C) 2020 by the authors. Licensee SSBFNET, Istanbul, Turkey. This article is an open access article distributed under the terms and conditions of the Creative Commons Attribution (CC BY) license (http://creativecommons.org/licenses/by/4.0/).

\section{Introduction}

According to Bullock, Kretch \& Candon (2008) and Forfás (2010) developing countries view sustainable development as a means of socio-economic upward mobility that will help solve their problems with poverty. Developing countries approach sustainable development from the viewpoint of a need within their countries for socioeconomic upward mobility and hence adoption of decentralization (OECD, 2010). Amolo (2010) affirms that African countries have increasingly adopted decentralization as a strategy to improve governance and to remedy institutional deficiencies that highly centralized governments have engendered. These include corruption and the marginalization of communities from the mainstream policy process. The literature on decentralization argues that the dispersing of power and authority increases discretion among local communities. Transparency can both be seen as an intrinsic value of democratic societies and as a means to achieve other important democratic goals such as enhancing accountability, trust, good governance or reducing corruption (Grimmelikhuijsen, 2012). In democratic systems citizens are kept informed by governments and others in the interests of transparency and accountability (Gaber, 2007).

Kenya is an East African nation that in 2014 was home to 45.5 million people (World Bank, 2016). It is one of East and Central Africa's most powerful economies with a GDP of 60.94 billion USD as of 2014 (World Bank, 2016). Nevertheless, Kenya is still considered by the World Bank to be a lower middle income nation, with GNI per capita in 2014 reaching only 1,280 USD (World Bank, 2016). This income status is reflected in the poverty rates across the country, where in 2009, $28.8 \%$ of Kenyans lived below the poverty line (of 1.25 USD per day), $24.4 \%$ were vulnerable to poverty, and $19.8 \%$ lived in severe poverty (World Bank, 2016). Despite devolution having been in place for several years, the counties are yet to achieve $100 \%$ utilization of funds allocation, this is mainly due to corruption (as supported by Amolo, 2010) and lack of transparency and effect of services delivery and thus need for this study.

\footnotetext{
* Corresponding author. ORCID ID: 0000-0002-1876-1786
}

(C) 2020 by the authors. Hosting by SSBFNET. Peer review under responsibility of Center for Strategic Studies in Business and Finance. https://doi.org/10.20525/ijrbs.v9i3.617 
Decentralization operates under the principle that decentralized systems have the advantage of having superior information on local needs and stronger incentives to address them. However, there are varying opinions on the impact of decentralization. Rondinelli et al (1999) noted that decentralization seldom, if ever, lived up its promise. On the other hand, in their review of more than 56 studies published since the late 1990's, Shah et al. (2004) found that decentralization improved service delivery, corruption and growth in some countries while worsening it across a large range of countries. There are many ways of improving transparency and main ones is participation and communication and according to World Bank (2015), public participation is critical for the successful performance of governments as it enables the public to determine and own their development objectives, a fact that has been realized by countries such as UK, USA, India and South Africa that have embraced this governance system. Despite the fact that efforts have been made in fostering Public Participation through legal frameworks in Kenya in the dawn of the 2010 Constitution (IEA, 2015), and whereas a study by the WB (2015) suggests a positive correlation between public participation and enhanced performance of states, actual performance of counties across Kenya has been dismal. A study by Khaunya, Wawire and Chepngeno (2015) supports this view and notes that there has been escalating unemployment in recent years, corruption, inadequate performance in infrastructure development, and service delivery in many counties in Kenya. This study sought to establish the level of transparency and its contribution on services delivery in 47 County Governments in Kenya.

The reminder of this study is organized as follows. The next section provides a review of extant literature. The third section introduces methodology and data. Finally, conclusions and implications of the study are presented in the final section.

\section{Literature review}

The good governance theory, developed by the United Nations Council in the 1990s emphasized sound public sector management, accountability, exchange and free flow of information and a legal framework for development (Keraro, 2014). This theory refers to measures that are designed to improve the overall performance of an organization (as a composition of sub-systems) by increasing its effectiveness and legitimacy. It advocates for the establishment of a solid foundation for management structures, public participation, policies and procedures which help institutions to fulfil their set goals. Although, this could lead to legal challenges, delays and cost to decisions, applying the governance theory in the management of devolved systems ensures full participation of all the stakeholders and sectors within the devolved governance systems.

\section{Transparency}

In much of the literature on transparency an automatic link is assumed between transparency and increased accountability (Naurin, 2007) or trust. However, this link is not as straightforward (Brandsma 2012, Meijer, 2013). Some scholars challenge that transparency leads to more trust (Meijer et al., 2012). While others argue (Fung and Weil, 2010) that government transparency with a focuses on accountability, could draw excessive attention to government's mistakes. A push for transparency may have reactionary effects of 'delegitimizing government activity quite broadly as public disclosure feeds more and more stories of government waste, corruption and failure' (Fung and Weil, 2010). Thus, transparency can also have unintended consequences. The risk of negative side effects should not stop governments from pushing towards transparency (Meijer et al, 2012); however these unintended consequences need to be identified so that possible future effects might be anticipated.

\section{Devolved governance}

Devolution is considered a form of political decentralization, involving a full transfer of responsibility, decision-making, resources and revenue generation to a local level of public authority that is autonomous and fully independent from the devolving authority. Decentralization is often linked to concepts of participation in decision-making, democracy, equality and liberty from higher authority (Dutta, 2009). The objectives of devolution in Kenya are stated under Article 174 of the Constitution (Republic of Kenya, 2010) and they are:

i. To promote democratic and accountable exercise of power;

ii. To foster national unity by recognizing diversity;

iii. To give powers of self-governance to the people and enhance the participation of the people in the exercise of the powers of the State and in making decisions affecting them;

iv. To recognize the right of communities to manage their own affairs and to further their development;

v. To protect and promote the interests and rights of minorities and marginalized communities;

vi. To promote social and economic development and the provision of proximate, easily accessible services throughout Kenya;

vii. To ensure equitable sharing of national and local resources throughout Kenya;

viii. To facilitate the decentralization of State organs, their functions and services, from the capital of Kenya; and,

ix. To enhance checks and balances and the separation of powers.

This shows that transparency is key in achieving the above mentioned objectives. This is why there are various strategies to ensure participation such as participation. 


\section{Public participation}

Public participation is seen as a form of empowerment and is a vital part of democratic governance. It is part of a "people first" or "people centered" methods of management, which avoids centralized, hierarchical decision-making. Participation is important because practical experience on the ground shows that it establishes the necessary sense of ownership. Generally people tend to resist new ideas if these are imposed on them, (Odhiambo and Taifa, 2009). The Kenyan constitution 2010 provides viable proposals aimed at achieving participatory governance. It is, however, critical to observe that devolution in itself will not enhance automatic citizen participation, (Republic of Kenya, 2010). First, it will be imperative that adequate civic education and awareness is provided so that citizens understand their responsibilities in a devolved system. Scholars have cited lack of capacity of many of the actors in developing countries as the reason for governmentse resistance to participation by the poor, who generally, have limited education, low literacy levels and hence deficient understanding of the policy process (Anwar, 2007). Muia and Oloo (cited in Omolo, 2010) assert that the main objective of decentralization is to bring about greater citizen participation and higher levels of accountability to citizens. This leads to institutional responsiveness in service delivery and low levels of corruption in government. Accountability to citizens increases in the face of reduced accountability to the central government

\section{Communication and transparency}

Ruler and Vercic (2012) provide an overview of all major approaches to communication, including both one-way and two approaches. According to Grunig (2008) the two-way symmetrical model is the most effective communication model. Grimmelikhuijsen (2012) refers to information usability and whether the information is timely and understandable or clear. Similarly, in the USA transparency has been promoted by several public advocacy organizations such as Sunshine Week and the Open Government Working Group (Popova-Nowak, 2011). These organizations have suggested eight fundamental principles regarding public access and use of government information: data should be complete, primary, timely, accessible, non-discriminatory, nonproprietary and license-free (Opengovdata.org, 2007). Using the internet to promote transparency is reasonable because of the technological capacity and because it meets the expectations of many members of the public (Jaeger and Bertot, 2010). Technologies can thus facilitate direct communication with target publics, bypassing media intervention. Social media have four potential strengths: collaboration, participation, empowerment and time (Bertot et al, 2010). However, as Sifry (2011) points out usage of social media like Twitter and Facebook have come to be seen of proof that government officials have embraced the network age when however most of the time they are still just talking at their constituents rather than with them. Thus, transparency is not only about information government wants to disclose (proactive) or has to disclose (reactive). It should also take into account the perspective of the receiver, or actor thereby looking at criteria such as whether the information is findable and relevant for its users. In addition, completeness, timeliness, accuracy and understandability are important as well. Technology has made it easier to disclose information and the amount of proactively disclosed information by the government is growing, yet achieving two-way communication with citizens needs more attention.

\section{Transparency and services delivery}

In a report evaluating 100 case studies that mapped the outcomes of citizen engagement, Gaventa and Barrett (2010) find over 30 cases in which significant impacts were made on service delivery, including in the health and education sectors. For example, in Brazil, participatory governance councils have been significant in improving access to and quality of health care services. In Bangladesh, parents of girls in schools mobilised to monitor teacher attendance and discourage absenteeism. While the methodology used to synthesise comparative findings advances the ways in which qualitative case material can be analysed, the cases cover all forms of citizen engagement and the study does not isolate the impact of services delivery. Finally, most importantly transparency initiatives without corresponding support for increasing the capacity to respond can lead to inaction and frustration on the part of providers (Gaventa and Barrett, 2010). This shows the transparency increases the services delivery.

\section{Research and methodology}

The study adopted mixed method approach using survey and in-depth interviews. Stratified multi stage cluster sampling was adopted in line with the structure of county governance provided for under Article 88 and 89 of the Constitution of Kenya, 2010. In this study it was important to understand level of transparency in the 47 counties in Kenya.

The constitution gives the Independent Electoral and Boundary Commission (IEBC) to set and review County, Constituency and Wards boundaries based on population quota (total population divided by total land area) with a deviation of $40 \%$ from the quota in urban/dense and sparsely populated area and 30\% in other area. Against this, the 47 Counties were categorized broadly into urban and rural and further into dense rural, rural and ASAL counties.

The study was carried out in all the 47 counties with the first strata (Primary Sampling Unit being the ward), then 7 households within the ward sampled randomly in which a randomly selected respondent was interviewed. The sample size based on $95 \%$ confidence level and 5\% margin of error was computed pivoted on Nairobi County population, the largest urban centre, and recalculated for all the other counties/ categories based on quota deviations. The urban counties under the study had a citizen sample size of 271, dense rural, 194, rural 150 and ASALs had a sample of 116. The citizen sample frame summed up to 7690 respondents across the country. Additionally, the study factored respondents from the county government officials with a sample frame comprising of 235 Members 
of the County Assembly, 47 speakers/deputy speakers, 47 clerks/deputy clerks, 47 County Executive Committee members and 47 County Secretaries.

\section{Data analysis}

This study sought to analyze the level of transparency and therefore both descriptive and statistical analysis was used. The study used descriptive analysis such as frequencies and percentages for background information and state of transparency. The survey also used descriptive statistics to analyse the degree if transparency; direction of transparency and distribution of transparency. Transparency was computed using the dimensions of transparency; Decision making, Policy making and Policy outcome (Table 1). The scores were later used to construct a typological theory for the classification of different transparency in the counties based on the interplay between levels of transparency scores on its dimensions. Descriptive statistics were used in this case to determine the proportion of transparency that fell into each of the categories. The second part of the study constructs a causal pathway that leads from antecedent conditions to the eventual outcome, using qualitative data from in-depth, key informant interviews. A theory-based analysis of how each transparency contributes to the outcome of dimensions of transparency is conducted using stories associated with such classifications. Finally, cross tabulation was conducted to establish the relationship between the two.

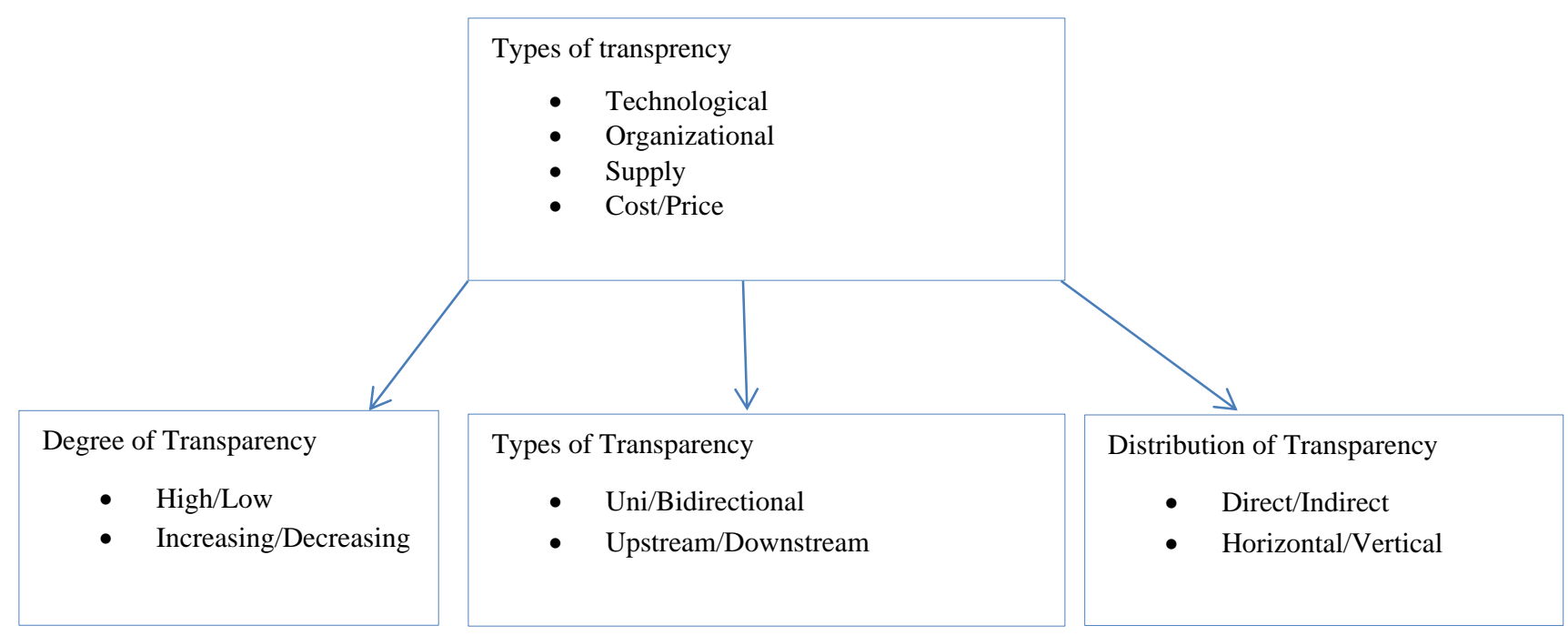

Fig. 1: Transparency; Source: Jens and Björn (2007).

Table 1: Dimensions of transparency

\begin{tabular}{llll}
\hline & Completeness & Color & Usability \\
\hline Decision making & $\begin{array}{l}\text { Complete information about } \\
\text { decision }\end{array}$ & $\begin{array}{l}\text { Information is reflecting all values } \\
\text { and opinions in the process }\end{array}$ & $\begin{array}{l}\text { Decision making process made insightful in a } \\
\text { timely and understandable manner }\end{array}$ \\
\hline $\begin{array}{l}\text { Policy making } \\
\text { Policy outcome }\end{array}$ & $\begin{array}{l}\text { All relevant policy plans and } \\
\text { measures are available }\end{array}$ & $\begin{array}{l}\text { Reflecting both negative and } \\
\text { positive issues about the policy }\end{array}$ & $\begin{array}{l}\text { Policy plans and measures are made insightful } \\
\text { in a timely and understandable manner }\end{array}$ \\
& $\begin{array}{l}\text { quantitative data about } \\
\text { relevant policy outcomes are } \\
\text { available }\end{array}$ & $\begin{array}{l}\text { Effects are determined } \\
\text { objectively, there is no room for }\end{array}$ & $\begin{array}{l}\text { Policy outcomes are made } \\
\text { insightful in a timely and } \\
\text { outcome }\end{array}$ \\
\hline
\end{tabular}

Source: Grimmelikhuijsen (2012).

\section{Findings}

\section{Demographics}

Citizens:

The citizen's survey reached 7632 respondents out of the target 7690, making a success rate of $99 \%$. These respondents were drawn from the 47 counties having 7 households within the ward sampled randomly and interviewed and quota deviations were considered for large counties. The urban counties under the study had a citizen sample size of 271, dense rural, 194, rural 150 and ASALs had 
a sample of 116 . The citizen sample frame summed up to 7690 respondents across the country. As shown in Figure 2 below, 4116 (54\%) of the respondents were male while $3516(46 \%)$ were female.

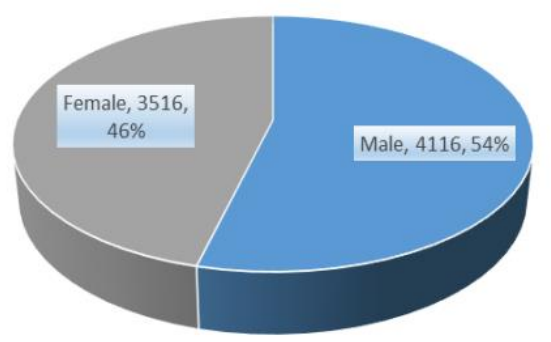

Fig. 2: Citizen's count by sex $(\mathrm{N}=7632)$

Most (36\%) of the citizen respondents were aged between 25 to 34 years followed by those aged between 35 and 44 years (25\%). The age with the least number of respondents was that of 18 to 24 years (18\%) as shown in Table 2 below.

Table 2: Citizen's by age group by sex $(\mathrm{N}=7632)$

\begin{tabular}{|c|c|c|c|c|c|c|}
\hline \multirow[t]{2}{*}{ Age } & \multicolumn{6}{|c|}{ Gender } \\
\hline & Male & & Female & & Total & \\
\hline $18-24$ & 689 & $51 \%$ & 657 & $49 \%$ & 1346 & $18 \%$ \\
\hline $25-34$ & 1434 & $53 \%$ & 1282 & $47 \%$ & 2716 & $36 \%$ \\
\hline $35-44$ & 983 & $52 \%$ & 902 & $48 \%$ & 1885 & $25 \%$ \\
\hline 45 and Above & 1010 & $60 \%$ & 675 & $40 \%$ & 1685 & $22 \%$ \\
\hline Total & 4116 & $54 \%$ & 3516 & $46 \%$ & 7632 & $100 \%$ \\
\hline
\end{tabular}

Asked about the highest level of education achieved, most (35\%) indicated that they had tertiary level education. 23\% reported having no formal education while $13 \%$ indicated having primary school education only. Other details are as shown in Table 3 below.

Table 3: Citizen's highest level of education by sex $(\mathrm{N}=7632)$

\begin{tabular}{|c|c|c|c|c|c|c|}
\hline \multirow[t]{2}{*}{ Education Level } & \multicolumn{6}{|c|}{ Gender } \\
\hline & Male & & Female & & Total & \\
\hline Primary School & 444 & $45 \%$ & 544 & $55 \%$ & 988 & $13 \%$ \\
\hline Secondary School & 1100 & $50 \%$ & 1082 & $50 \%$ & 2182 & $29 \%$ \\
\hline Tertiary & 1498 & $56 \%$ & 1183 & $44 \%$ & 2681 & $35 \%$ \\
\hline Informal/None & 1074 & $60 \%$ & 707 & $40 \%$ & 1781 & $23 \%$ \\
\hline Total & 4116 & $54 \%$ & 3516 & $46 \%$ & 7632 & $100 \%$ \\
\hline
\end{tabular}

Majority $(51 \%)$ of the respondents reported being either self-employed or employed in a family business. However, as shown in Table 4 below, $23 \%$ of the respondents indicated that they were unemployed. This may be an indication of the low levels of household income where $39 \%$ reported to be earning less than KES 5,000/- per month. 1\% of the citizens indicated to be earning KES 100,000/and above per month. 
Table 4: Citizen's employment status and monthly HH income by sex $(\mathrm{N}=7632)$

\begin{tabular}{|c|c|c|c|c|c|c|}
\hline \multirow{2}{*}{$\begin{array}{l}\text { Employment Status } \\
\text { Student }\end{array}$} & \multicolumn{2}{|l|}{ Male } & \multicolumn{2}{|c|}{ Female } & \multicolumn{2}{|l|}{ Total } \\
\hline & 284 & $53 \%$ & 256 & $47 \%$ & 540 & $7 \%$ \\
\hline Unemployed & 792 & $46 \%$ & 940 & $54 \%$ & 1732 & $23 \%$ \\
\hline Self Employed/Employed in family business or farm & 2102 & $54 \%$ & 1792 & $46 \%$ & 3894 & $51 \%$ \\
\hline Employed in Private Sector & 416 & $60 \%$ & 275 & $40 \%$ & 691 & $9 \%$ \\
\hline Employed by government/county/parastatal & 300 & $63 \%$ & 176 & $37 \%$ & 476 & $6 \%$ \\
\hline Employed in community sector & 78 & $67 \%$ & 39 & $33 \%$ & 117 & $2 \%$ \\
\hline Retired & 144 & $79 \%$ & 38 & $21 \%$ & 182 & $2 \%$ \\
\hline Total & 4116 & $54 \%$ & 3516 & $46 \%$ & 7632 & $100 \%$ \\
\hline \multicolumn{7}{|l|}{ HH Income Per Month } \\
\hline Less than 5,000 & 1419 & $48 \%$ & 1543 & $52 \%$ & 2962 & $39 \%$ \\
\hline $5,000-9,999$ & 944 & $54 \%$ & 796 & $46 \%$ & 1740 & $23 \%$ \\
\hline $10,000-24,999$ & 823 & $62 \%$ & 496 & $38 \%$ & 1319 & $17 \%$ \\
\hline $25,000-49,999$ & 426 & $69 \%$ & 190 & $31 \%$ & 616 & $8 \%$ \\
\hline $50,000-99,999$ & 124 & $71 \%$ & 50 & $29 \%$ & 174 & $2 \%$ \\
\hline 100,000 and Above & 34 & $69 \%$ & 15 & $31 \%$ & 49 & $1 \%$ \\
\hline Refused to answer & 346 & $45 \%$ & 426 & $55 \%$ & 772 & $10 \%$ \\
\hline Total & 4116 & $54 \%$ & 3516 & $46 \%$ & 7632 & $100 \%$ \\
\hline
\end{tabular}

\section{County assembly (MCAs)}

From the target sample of 235 Members of the County Assembly (MCA), 144 were reached during the study representing $61 \%$ response rate. Majority (71\%), of the MCAs indicated that they were elected into office. However, this is an aggregate represented by $88 \%$ male and $12 \%$ female. This goes to show that few females vie for public office. As shown in Table 4 below, $74 \%$ of the female MCAs were noted to be nominated members. There are 70\% male MCAs and 30\% females within the counties.

Table 5: MCAs designation by sex $(\mathrm{N}=144)$

\begin{tabular}{lllllll}
\hline MCA designation & \multicolumn{2}{l}{ Male } & \multicolumn{3}{c}{ Female } & \multicolumn{2}{c}{ Total } \\
\hline Elected & 90 & $88 \%$ & 12 & $12 \%$ & 102 & $71 \%$ \\
\hline Nominated & 11 & $26 \%$ & 31 & $74 \%$ & 42 & $29 \%$ \\
\hline Total & $\mathbf{1 0 1}$ & $\mathbf{7 0 \%}$ & $\mathbf{4 3}$ & $\mathbf{3 0 \%}$ & $\mathbf{1 4 4}$ & $\mathbf{1 0 0 \%}$
\end{tabular}

Of the target 47 speakers/deputy speakers, 47 clerks/deputy clerks, the study reached 68 officials as shown in Figure 3 below. There were $31(46 \%)$ speakers and 37 (54\%) clerks who responded to the questionnaires.

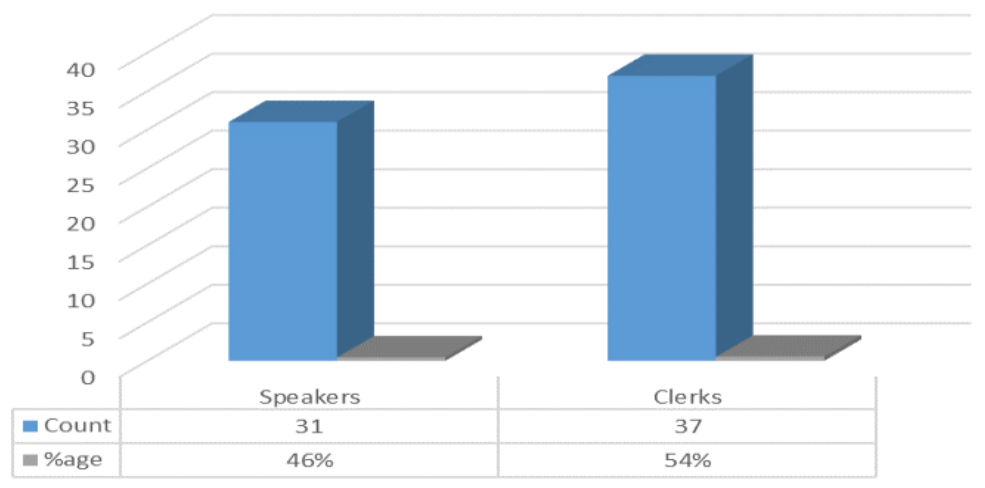

Fig. 3: County Assembly officials ( $\mathrm{N}=68)$ 


\section{County executives}

The study targeted to reach 94 county executives but instead reached 34 (36\%). The responses were from 36 counties with 46 assemblies being represented. Although the number reached was below the target, the findings were statistically sound. Majority of the executives reached were county secretaries (53\%) as shown in Table 6 below.

Table 6: County executives by designation $(\mathrm{N}=34)$

\begin{tabular}{lll}
\hline Designation & Count & \%age \\
\hline Dep County Secretary & 2 & $6 \%$ \\
\hline Ag. County Secretary & 1 & $3 \%$ \\
\hline Asst. County Secretary & 1 & $3 \%$ \\
\hline CEC & 1 & $3 \%$ \\
\hline CEC culture & 1 & $3 \%$ \\
\hline CEC Education, sports & 1 & $3 \%$ \\
\hline CEC land & 1 & $3 \%$ \\
\hline CEC lands, environment & 1 & $3 \%$ \\
\hline CEC public service & 1 & $3 \%$ \\
\hline Chief of staff & 2 & $6 \%$ \\
\hline Chief Officer Public service & 1 & $3 \%$ \\
\hline County Secretary & 18 & $53 \%$ \\
\hline Dep County Secretary & 1 & $3 \%$ \\
\hline Director of Administration & 2 & $\mathbf{1 0 0}$ \\
\hline Total & $\mathbf{3 4}$ & \\
\hline
\end{tabular}

\section{Transparency}

County executives have put in place certain mechanisms in the counties in order to disseminate information. In looking at the mechanisms, the study also sought to know the frequency of use as well as the kind of information that is generally shared using the said mechanism. It emerged that there is no standard tool that is used for all kinds of information.

As shown in Table 7 below, the county websites are used by $91 \%$ by the public in seeking information with a frequency rate of $44 \%$. They most common nature of information sought was said to be in regard to the county project being undertaken as reported by $45 \%$. Facebook is used by $79 \%$ with a frequency rate of $57 \%$ with $46 \%$ saying that they sought current updates and events. 53\% indicated that they use twitter with $33 \%$ indicating that they did so frequently. They use the tool for both public consumption as well as official communication as reported by $54 \% .88 \%$ reportedly use WhatsApp at a frequency rate of $68 \%$. They use the tool for internal office communication as reported by $44 \%$.

The noticeboard is said to be used by $82 \%$ of the public with a frequency rate of $74 \%$. They were said to be seeking information regarding job and tender adverts as reported $64 \% .88 \%$ were said to use newspapers at a frequency of $44 \%$. The information sought was on job and tender adverts as reported $61 \%$.

The national radio was said to be used by $71 \%$ with a frequency rate of $20 \%$. The public was said to use this to listen to governor's interviews as they share information on projects and also for adverts and tenders as indicated by $38 \%$ of the respondents. Local radio was said to be used by $79 \%$ of the people at a frequency rate of $57 \%$. The main information sought was said to be adverts, tenders and announcements as well as civic education as mentioned by $30 \%$ of the respondents.

National TV was said to be used by $74 \%$ with a frequency rate of $20 \%$ and similar usage as the local radio as reported by $42 \%$ of the respondents. Local TV was also used for the same reason by $54 \%$ by $50 \%$ at a rate of $27 \%$. The community and town hall meetings are used by $88 \%$ of the public at a frequency rate of $57 \% .93 \%$ were reported to use the facilities for seeking for projects and public participation. 
Table 7: Transparency and public participation mechanisms $(\mathrm{N}=34)$

\begin{tabular}{llll}
\hline Mechanism & Usage & Frequency & Nature of information \\
\hline Website & $91 \%$ & $44 \%$ & County projects being undertaken (45\%) \\
\hline Facebook & $79 \%$ & $57 \%$ & Current update and events (46\%) \\
\hline Twitter & $53 \%$ & $33 \%$ & Public consumptions, official communication (54\%) \\
\hline WhatsApp & $88 \%$ & $68 \%$ & Internal/office use (44\%) \\
\hline Notice board & $82 \%$ & $74 \%$ & Job and tender adverts (64\%) \\
\hline Newspapers & $88 \%$ & $44 \%$ & Job and tender adverts (61\%) \\
\hline National radio & $71 \%$ & $20 \%$ & Governors interviews giving information on projects, adverts and tenders (38\%) \\
\hline Local radio & $79 \%$ & $57 \%$ & Adverts, tenders and announcements, civic education (30\%) \\
\hline National TV & $74 \%$ & $20 \%$ & Adverts, tenders and announcements, civic education (42\%) \\
\hline Local TV & $50 \%$ & $27 \%$ & Adverts, tenders and announcements, civic education $(54 \%)$ \\
\hline $\begin{array}{l}\text { Community/ town hall } \\
\text { meetings }\end{array}$ & $88 \%$ & $57 \%$ & Projects to be done, public participation (93\%) \\
\hline
\end{tabular}

The County Integrated Development Plan (CIDP) was reportedly simplified for public consumption as stated by $78 \%$ of the respondents. 24\% indicated that it had been translated in the local language with $6 \%$ said that it had been presented in braille. The Annual Development Plan (ADP) was said to be simplified as reported by $77 \%$.

Those who indicated that it had been translated into the local language were $8 \%$ while a similar number indicated that it had been presented in braille. The budget was said to have been simplified by $78 \%$ of the respondents. $17 \%$ said that it had been translated into the local language while $8 \%$ said it had been presented in braille. A general overview indicates that these important documents need to be translated in to the local languages as well as presented in braille for more transparency. See Table 8 below.

Table 8: County document status $(\mathrm{N}=34)$

\begin{tabular}{|c|c|c|c|c|c|c|c|}
\hline \multicolumn{2}{|l|}{ Document } & \multicolumn{2}{|c|}{ Simplified } & \multicolumn{2}{|l|}{ Translated into local language } & \multicolumn{2}{|c|}{ Presented in braille } \\
\hline CIDP & Yes & 21 & $78 \%$ & 4 & $24 \%$ & 1 & $6 \%$ \\
\hline & No & 6 & $22 \%$ & 13 & $77 \%$ & 15 & $94 \%$ \\
\hline \multirow[t]{2}{*}{ ADP } & Yes & 17 & $77 \%$ & 1 & $8 \%$ & 1 & $8 \%$ \\
\hline & No & 5 & $23 \%$ & 11 & $92 \%$ & 12 & $92 \%$ \\
\hline \multirow[t]{2}{*}{ Budget } & Yes & 18 & $78 \%$ & 2 & $17 \%$ & 1 & $8 \%$ \\
\hline & No & 5 & $22 \%$ & 10 & $83 \%$ & 11 & $92 \%$ \\
\hline
\end{tabular}

\section{Typological theory of Transparency}

To determine the difference in transparency in the counties and its implication of various dimensions, it was necessary to classify transparency based on the types found in the counties (direction of transparency and distribution of transparency) based on the score achieved through the aggregate of the three. While the dimensions aggregate were achieved through using the three dimensions (Decision making, Policy making and Policy outcome). An appropriate analytic tool for this approach is typological theory (Bennett 2013; George and Bennett 2005; Cornelissen 2016; Fiss 2011, Daniel, 2017). According to Bailey (1994), theory-based typologies can effectively be subjected to rigorous empirical testing using the quantitative models.

The aggregate were divided into three sub-groups with 1 being low, 2 medium and 3 high. All scores above the mean were considered high and those below the mean were considered low. In the current paper two dimension figure with four-quadrants was developed. As shown figure 4, 5 and 6 the $y$-axis indicates Transparency while $\mathrm{x}$-axis Represent service delivery. All scores were between 1 and 3 and those above the mean of 2 were considered high transparency and those below the mean were considered low transparency. 


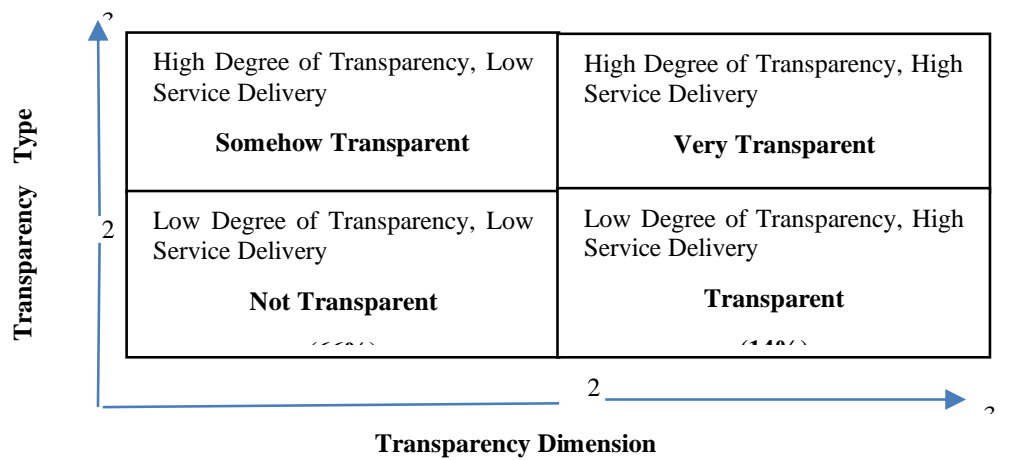

Fig. 4: Typology of Degree Transparency and Service Delivery

The study used the degree of transparency and service delivery to establish the extent of transparency in counties and $66 \%$ are not transparent, $6 \%$ somewhat transparent, $14 \%$ transparent and 14\% very transparent as illustrated in Figure 4 . This means that in regards to degree of transparency in the counties majority of them are not transparent.

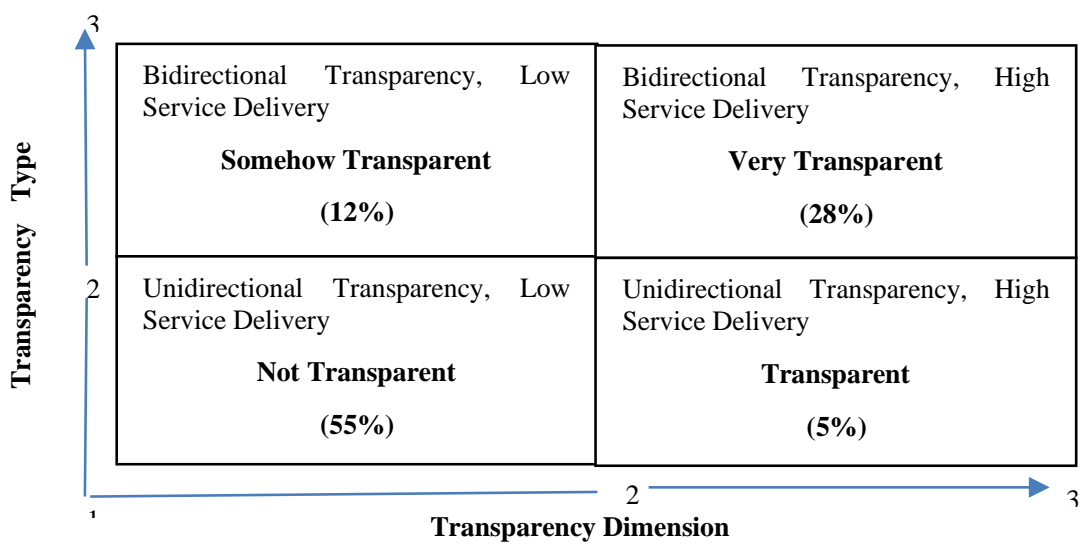

Figure 5: Typology of Direction Transparency and Service Delivery

The paper further sought to establish the direction of transparency in counties in Kenya, 55\% were not transparent, this shows that transparency in county governments is one direction (from the leaders and management of counties) and not shared from both leaders and stakeholders as shown in Figure 5.

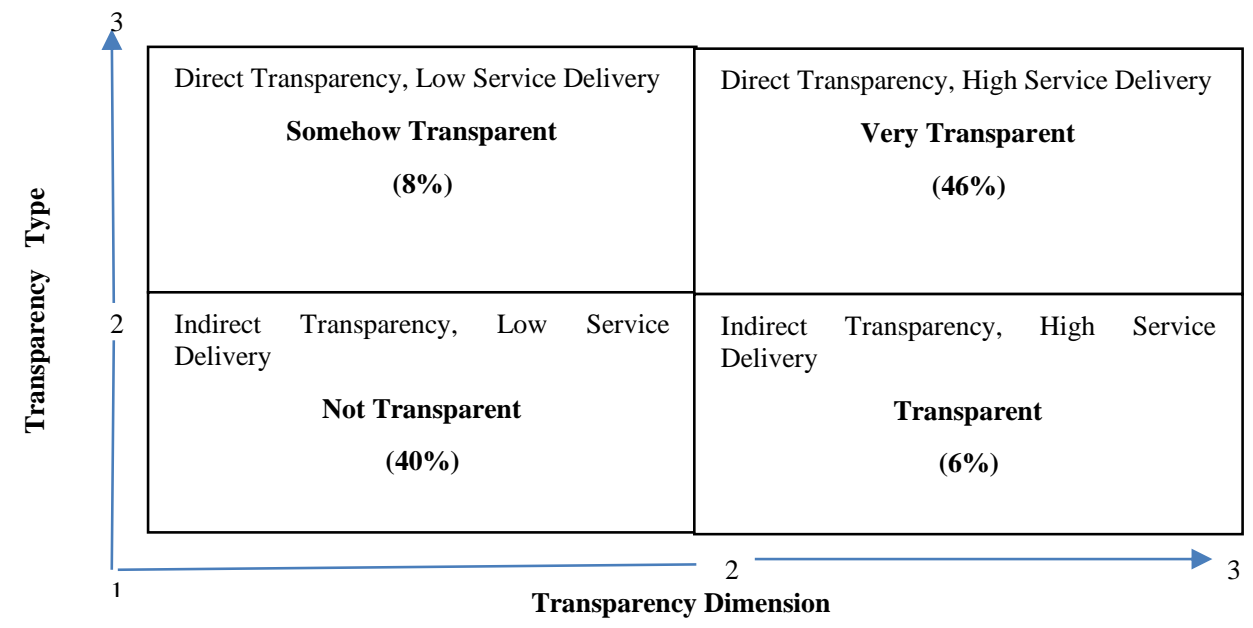

Fig. 6: Typology of Distribution Transparency and Service Delivery 
Study also sought to find out the distributions of transparency in the counties, according $46 \%$ state that it is very transparent while $40 \%$ not transparent as shown in Figure 6. This shows that direct transparency plays a higher role in the service delivery in the counties but at the same time indirect transparency leads to low level of implementation of services in the counties.

\section{Hypothesis Testing}

\section{Convergent Validity of Transparency}

This implies that the indicators were significantly related to transparency and the results verified the convergent validity of transparency construct. Overall the results shows that relationship between transparency and service delivery is positive and significant (Estimate $=.412, \mathrm{CR}=4.910, \mathrm{p}$-value $=0.000$. This implies that an increase in transparency lead to increase in service delivery by .412 units in the counties.

Table 9: Regression Weight and CR Values for Transparency

\begin{tabular}{llccccc}
\hline & & Estimate & S.E. & C.R. & P-value \\
\hline $\mathbf{S}$ & $<---$ & $\mathrm{T}$ & .412 & .084 & 4.910 & $* * *$ \\
\hline $\mathrm{DR} 1$ & $<---$ & $\mathrm{T}$ & .765 & .098 & 7.806 & $* * *$ \\
\hline $\mathrm{DR} 2$ & $<---$ & $\mathrm{T}$ & .656 & .084 & 7.831 & $* * *$ \\
\hline DR3 & $<---$ & $\mathrm{T}$ & .831 & .102 & 8.168 & $* * *$ \\
\hline
\end{tabular}

The study used structural Model 7 represented Structural Equation Modeling (SEM) for transarency and service delivery as shown in figure 8. Path coefficients were used to determine the direction and strength of the factor. The figure shows a path coefficient beta value of .75 $(\beta=.75)$. This implies that for every 1 unit increase in transparency, services delivery is predicted to decrease by .75 units. $\mathrm{R}_{2}$ was used to show the proportion of variation in dependent variable explained by the SEM model. The figure also shows that transparency had a coefficient $\mathrm{R}_{2}$ mean of .56 . The value of $\mathrm{R}_{2}$ of .56 indicates that $56 \%$ of the variations in services delivery in county governments can be accounted for by transparency.

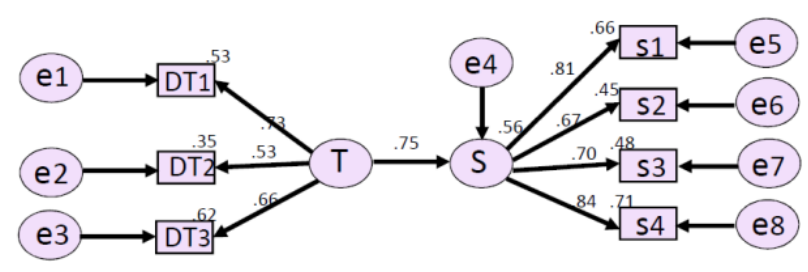

Fig. 7: Structural Equation Modeling (SEM) for Transparency and Service Delivery

\section{Conclusions}

Transparency in the public service remains a critical for efficient service delivery in the county governments. Whilst there is substantial debate about direct transparency playing a higher role in the service delivery in the counties there is low debate about indirect transparency leading to low level of implementation of services in the counties. The study structural Equation Modelling (SEM) for transparency and service delivery shows a path coefficient beta value of $.75(\beta=.75)$ implying that for every 1 unit increase in transparency, services delivery is predicted to decrease by .75 units. $56 \%$ of the variations in services delivery in county governments can be accounted for by transparency. As Keraro (2014) argues the good governance theory, developed by the United Nations Council in the 1990s emphasized sound public sector management, accountability and transparency as framework for development. Although many of the failures of devolution have been blamed on inadequate fund allocation from National Government for service delivery it is argued in this study that it is important to look beyond funding.

In the county governments the level of transparency is measured based on degree, direction and distribution of transparency implemented by the county government. The transparency should include the stakeholders which in this case is the communities, suppliers and the National government at large. From the study it was established the degree of transparency in the county governments was low. This is because the counties have concentrated on sharing information through social media, the websites and other electronic and printed media to show the public that they are open about what is being implemented. However, before the information is shared the modalities of arriving at the information is not explained and the shareholders are not involved. The involvement of the community members in budget is merely passing of already formed document and it's upon the public to rubberstamp it. It is acknowledged that the relationship between transparency and service delivery can be complex, however its role still remain distinct and a major factor of consideration. 
This study provides critical insights into how transparency contributes to service delivery and it is evident that there is very limited involvement in designing of the budget and distribution of the funds among various projects in the county wards. This shows that the direction of transparency is mainly unidirectional and the distribution is indirect. There is need for the counties to involve the communities more in every decision that is being made especially regarding the projects that will affect them. Future continental comparative studies can be conducted to provide important insights from countries that started devolved government earlier than Kenya.

\section{References}

African Union Commission (2015). Agenda 2063: The African We Want: First Ten-Year Implementation Plan, 2014-2023 Addis Ababa: African Union Commission

Amolo, A. (2010). Devolution in Kenya: a critical review of past and present frameworks. In A. Mwenda. ed. Devolution in Kenya: prospects, challenges and future. Nairobi: Institute of Economic Affairs. pp. 13-47.

Anuradha, J (2013). Do They Work? Assessing the Impact of Transparency and Accountability Initiatives in Service Delivery. Development Policy Review 31(1), 29-48, http://dx.doi.org/10.1111/dpr.12018

Anwar S. (2007) Participatory Budgeting. Washington, DC The World Bank

Bailey, K.D. (1994) Typologies and Taxonomies: An Introduction to Classification Techniques, 102: Thousand Oaks CA: Sage Publications.

Bennett, A. (2013). The Mother of all Isms: Causal Mechanisms and Structured Pluralism in International Relations Theory. European Journal of International Relations 19(3), 459- 81. https://doi.org/10.1177\%2F1354066113495484

Bertot, J.C., Jaeger, P.T. and Grimes, J.M. (2010). Using ICT's to create a culture of transparency: E-government and social media as openness and anti-corruption tools for society. Government Information Quarterly 27(3), 264-271. https://doi.org/10.1016/j.giq.2010.03.001

Brandsma, G.J. (2012). The effect on oversight: the European Parliament's response to increasing information on comitology decision-making. International Review of Administrative Sciences 78(1), 74-91. https://doi.org/10.1177\%2F0020852311429756

Bullock, C., Kretch, C. \& Candon, E. (2008). The Economic and Social Aspects of Biodiversity Benefits and Costs of Biodiversity in Ireland. Retrieved from http://www.npws.ie/en/media/NPWS/Publications/Biodiversity/Media,6432,en.pdf.

Cornelissen, J. (2016). Developing Propositions, A Process Model or a Typology? Addressing the Challenges of Writing Theory without a Boilerplate. Academy of Management Review 42(1),1-9. https://doi.org/10.5465/amr.2016.0196

Daniel D. (2017). Staff Quality and Service Delivery: Evaluating Two Ghanaian District Assemblies. Institute of Development Studies | bulletin.ids.ac.uk. 48(2).

Dutta, S. (2009). Democratic decentralization and grassroot leadership in India, Mittal Publications, 2009, 5-8, ISBN 9788183242738 .

Fiss, P.C. (2011). Building Better Causal Theories: A Fuzzy Set Approach to Typologies in Organization Research. Academy of Management Journal 54(2), 393-420. https://doi.org/10.5465/amj.2011.60263120

Forfás (2010). Adaptation to Climate Change: Issues for Business.

Fung, A. (2006). Varieties of participation in complex governance. Public administration review. 66(6). 66-75.

Fung, A. and Weil, D. (2010). Open Government and Open Society. In: Lathrop, D. and Ruma, L. Open Government. Collaboration, Transparency and Participation in Practice. Sebastopol CA: O’Reilly Media Inc 105-113.

Gaber, I. (2007). Too much of a good thing: the "problem" of political communications in a mass media democracy. Journal of Public Affairs, 7, 219-234. https://doi.org/10.1002/pa.266

Gaventa, J. And Barrett, G. (2010). So What Difference Does it Make? Mapping the Outcomes of Citizen Engagement", IDS Working Paper 347.

George, A.L. and Bennett, A. (2005) Case Studies and Theory Development in the Social Sciences. Cambridge MA: MIT Press.

Grimmelikhuijsen, S. (2012). Transparency and Trust. An experimental study of online disclosure and trust in government. Dissertation, Utrecht University.

Grunig, J. (2008). Conceptualizing quantitative research in public relations. In B. van Ruler, A.T. Vercic, \& D. Vercic (Eds.) Public relations metrics: research and evaluation (pp. 88-119) New York and London: Routledge.

Howard W (2001) 'implementing effective ethics standards in government and the civil service' Transparency International. https://www.oecd.org/mena/governance/35521740.pdf

Institute of Economic Affairs (2015). Social Accountability; The Why and How. Nairobi, Kenya

International Framework: Good Governance in the Public Sector by IFAC (2014). International Framework: Good Governance in the Public Sector. NewYork, USA

Jaeger, P. T. and Bertot, J. (2010) Transparency and technological change: Ensuring equal and sustained public access to government information. Government Information Quarterly 27(4), 371-376. https://doi.org/10.1016/j.giq.2010.05.003

Jens H. AND Björn A. (2007). Towards a typology of transparency for marketing management research. industrial Marketing Management, 36(5), 627-635. https://doi.org/10.1016/j.indmarman.2006.04.001 
Kaufmann, Daniel; Kraay, Aart; Mastruzzi, Massimo (2005). Governance Matters IV : Governance Indicators for 1996-2004. Policy Research Working Paper; No. 3630. World Bank, Washington, DC. ㅇ World Bank. https://openknowledge.worldbank.org/handle/10986/

Kenya Anti-Corruption Commission. (2010). Sectoral Perspectives on Corruption in Kenya: The Case of Public Health Care Delivery. Nairobi: Kenya Anti-Corruption Commission.

Kenya, Republic of (2010). Laws of Kenya: The Constitution of Kenya. Nairobi: National Council of Law Reporting.

Keraro, V. N. (2014). Role of Governance in the Strategic Management of Counties in Kenya. Unpublished PhD Thesis, Juja: Jomo Kenyatta University of Agriculture and Technology.

Khaunya, M.F., Wawire B, P. \& Chepngeno, V. (2015). Devolved Governance in Kenya: is it a false start in democratic decentralization development.? International Journal of Economics, Finance and Management, 4.

Mame, D, Dena R, and Salman, Z (2012) Governance and Public Service Delivery in Europe and Central Asia: Unofficial Payments, Utilization and Satisfaction. The World Bank

Mburu F (1981). Socio-political imperatives in the history of health development in Kenya. Social Science and Medicine Journal 15(5), 519-741. https://doi.org/10.1016/0271-7123(81)90074-2

Meijer, A.J. (2013). Introduction to the special issue on government transparency. International Review of Administrative Sciences, 78(1), 3-9. https://doi.org/10.1177\%2F0020852311435639

Meijer, A.J. , Curtin, D. and Hillebrandt, M. (2012). Open government: connecting vision and voice. International Review of Administrative Sciences, 78(1), 10-29.

Mwenda, S. (2015). Corruption in Museveni's Uganda Is a System of Government. Sunday Monitor.

Naurin, D. (2007). Transparency, publicity, accountability- The missing links. Swiss Political Science Review. 12(3), 90-98. http://hdl.handle.net/1814/6610

Odhiambo, M. \& Taifa, A. (2009). Devolved Funds Development: A Handbook on Participation. Nairobi: Claripress.

OECD (2010). OECD Environmental Performance Reviews: Ireland.

Omolo, A. (2010). Devolution in Kenya: a critical review of past and present frameworks. In A. K. Mwenda, Devolution in Kenya, prospects, challenges, and the future pp. 8-47. Nairobi: Institute of Economic Affairs.

Opengovdata (2007). Eight principles of open government data. https://opengovdata.org/ downloaded 2nd March, 2020.

Paolo Mauro (1995). Corruption and Growth. The Quarterly Journal of Economics. 110(3), 681-712

Popova-Nowak, I.V. (2011). What is Transparency? In: Burke, W. M. and Teller, M. A Guide to Owning Transparency. How Federal Agencies Can Implement and Benefit from Transparency. Open Forum Foundation, Washington.

Rachel Gisselquist (2012). “What Does 'Good Governance’ Mean?” United Nations University.

Republic of Kenya (2010). The Constitution, Government Press, Nairobi

Rondinelli, D., 1999. What is Decentralization? In: Litvack, J., \& Seddon, J., 1999. Decentralization Briefing Notes. World bank Intitute working Papers. Pp. 2-5. [Online] Available at http://wwwwds.worldbank.org/servlet/WDSContentServer/WDSP/IB/1999/11/04/00009494 6_99101505320840/Rendered/PDF/multi_page.pdf [Accessed December, 2019]

Ruler, van, B. and Verčič, D . (2012). Reflective Communication Management Future Ways for Public Relations Research. In: Ruler, B. (2012). Met het oog op Communicatie. Reflecties op het communicatievak. Den Haag, Boom Lemma Uitgevers.

Shah, Anwar and Theresa Thompson, (2004). "Implementing Decentralized Local Governance: Treacherous Road with Potholes, Detours and Road Closures. ” Policy Research Working Paper 3353. World Bank, Washington, D.C.

Sifry, M. L. (2011) Wikileaks and the Age of Transparency. Berkely: Counterpoint

World Bank (2016) Access to Electricity (\% of Population). Available at: http://data.worldbank.org/indicator/EG.ELC.ACCS.ZS/countries.

World Bank, (2015). Building public participation in Kenya's devolved government CDS paper 1-6 series. Nairobi: Kenya School of Government.

World Bank, (2015). Storm Clouds Gathering: The Economy Facing Strong Headwinds with a special focus of Public Participation. The World Bank Group. Nairobi, Kenya: WB. 